\title{
28 Research Suare \\ Benefit of combining curcumin, harpagophytum and bromelain to reduce inflammation in osteoarthritic synovial cells
}

Sybille Brochard

Normandie Univ, UNICAEN

Julien Pontin

Normandie Univ, UNICAEN

Benoit Bernay

Normandie Univ, UNICAEN

Karim Boumediene

Normandie Univ, UNICAEN

Thierry Conrozier

Nord Franche-Comté Hospital

Catherine Baugé ( $\nabla$ catherine.bauge@unicaen.fr)

Normandie Univ, UNICAEN

\section{Research Article}

Keywords: Osteoarthritis, osteoarthritic synovial cells, inflammation, curcumin, harpagophytum, bromelain

Posted Date: April 8th, 2021

DOl: https://doi.org/10.21203/rs.3.rs-379634/v1

License: (9) This work is licensed under a Creative Commons Attribution 4.0 International License.

Read Full License

Version of Record: A version of this preprint was published at Osteoarthritis and Cartilage on April 1st, 2021. See the published version at https://doi.org/10.1016/j.joca.2021.02.556. 


\section{Abstract}

Background: Osteoarthritis is the most common cause of arthritis affecting millions of people worldwide, characterized by joint pain and inflammation. It is a complex disease involving inflammatory factors and affecting the whole joint including synovium. Since drug combination is widely used to treat chronic inflammatory diseases, a similar strategy may be worth of interest to design plant-derived natural products to reduce inflammation in OA joint. Here, we characterized the response of OA synovial cells to lipopolysaccharide (LPS) and investigated the biological action of the combination of curcumin, harpagophytum and bromelain in this original in vitro model of osteoarthritis.

Methods: Primary, human synovial cells from OA patients were stimulated with LPS and proteomic analysis was performed. Bioinformatics analysis were performed using Cytoscape App and SkeletalVis databases. Additionally, cells were treated with curcumin, harpagophytum and bromelain alone or the three vegetal compounds together. The expression of genes involved in inflammation, pain or catabolism were determined by RT-PCR. The release of the encoded proteins by these genes and of prostaglandin E2 (PGE2) were also assayed by ELISA.

Results: Proteomic analysis demonstrated that LPS induces the expression of numerous proteins involved in OA process in human OA synovial cells. In particular, it stimulates inflammation through the production of pro-inflammatory cytokines (Interleukin-6, IL-6), the catabolism through an increase of metalloproteases (MMP-1, MMP-3, MMP-13), and the production of pain-mediating neurotrophin (Nerve Growth Factor, NGF). These increases were observed at level of mRNA levels and of protein release. LPS also increases the amount of PGE2, another inflammation and pain mediator. At doses tested, vegetal extracts had little effects: only curcumin slightly counteracted the effects of LPS on NGF and MMP13 mRNA, and PGE2, IL-6 and MMP13 release. In contrast the association of curcumin with harpagophytum and bromelain reversed lots of effects of LPS in human OA synovial cells. It significantly reduced the gene expression and/or the release of proteins involved in catabolism (MMP3 and 13), inflammation (IL6) and pain (PGE2 and NGF).

Conclusion: We show that the stimulation of human OA synovial cells with LPS permit to induce protein changes similar to an inflamed OA synovial tissues. In addition, using this model, we demonstrate that the combination of three vegetal compounds, namely curcumin, harpagophytum and bromelain have anti-inflammatory and anti-catabolic action in synovial cells and may thus reduce OA progression and related-pain.

\section{Introduction}

Osteoarthritis $(\mathrm{OA})$ is a debilitating and painful disease characterized by inflammation of the synovial membrane and the progressive destruction of articular cartilage [1,2]. It is one of the top ten causes of physical disability [3]; however, its etiology and pathogenesis are still not fully understood. Long 
considered as a simple cartilage degenerative disease, $\mathrm{OA}$ is now described as a global joint chaos [4]. To date, no treatment has been able to reverse or alter OA progression.

Although $\mathrm{OA}$ is not classified as an inflammatory disease, many reports suggested that inflammation could be a major driver of OA development. Actually, elevated joint inflammation has been correlated with progression to the disease [5]. Thus, although OA pathogenesis remains unclear, inflammation is widely regarded as an extremely important factor for progression of this disease $[2,6-8]$.

Synovitis, i.e. inflammation of synovial tissues, is common in OA [9], and is mediated, in part, by fibroblast like synoviocytes (FLS). These cells play an important factors in OA inflammation and joint destruction, primarily by secreting a wide range of proinflammatory mediators, such as IL-6 and prostaglandin E2 (PGE2) [9], which leads the release of neurotrophins, such as NGF, participating to pain during OA, as well as the secretion of various type of proteases, including MMPs and a disintegrin and MMP with thrombospondin motifs (ADAMTS) [10], promoting the degradation of extracellular cell matrix (ECM), and further aggravating the progression of OA. Therefore, alleviating synovial inflammation may prevent the onset or minimize the progression of OA and symptoms [2,11-13]. Conventional antiinflammatory drugs are nonsteroidal anti-inflammatory drugs (NSAIDs) [14], however, they have several side effects and drug interactions including the risk of gastrointestinal, cardiovascular, and kidney problems. Used natural compounds may be a relevant alternative.

Herbal medicine has been used from ancient times to the present day for healing purposes. Curcumin (CUR) which is extracted from the rhizome of Curcuma longa L. is one of the most ancient medicinal herbs and is broadly used in human health due to its various therapeutic effects such as antiinflammatory, antioxidant, anticancer and antimicrobial [15]. In patients with OA, oral administration of curcumin ameliorates the clinical manifestations of the disease [16-19], improves quality of life and enables a decrease in the consumption of NSAIDs [20]. This beneficial effect of curcumin is associated to its ability to reduce $O A$ inflammation in cells, animal models, and human studies [21,22]. The action of curcumin may be reinforced by combination with other natural compounds $[15,23]$.

The purpose of the present study was to investigate the effects of the combination of curcumin (CUR), bromelain (BRO), a food obtained from pineapple and having analgesic properties [24], and harpagophytum (HAR), a traditional remedy for articular diseases [25]), on inflammation in an original experimental in vitro model of osteoarthritis, using human synovial cells treated with lipopolysaccharide (LPS).

\section{Material And Methods}

\section{Reagents}

Lipopolysaccharide (LPS) from E.Coli, Sigma Aldrich, Saint Louis, USA) was dissolved in phosphate buffer saline without Calcium and Magnesium (DPBS, Lonza, Bâle, Suisse), to reach a concentration of 1 $\mathrm{mg} / \mathrm{ml}$ and used at a final concentration of $1 \mu \mathrm{g} / \mathrm{ml}$. Curcumin (Tumeric extract granule, $95 \%$ 
curcuminoids, Natural, St Sylvain d'Anjou, France) was resuspended in dimethylsulfoxide (DMSO, Dutscher, Bernolsheim, Belgium). Bromelain (Bromelain 2500 GDU, Cambridge Commodities Ltd, Ely, UK) and Harpagophytum (Harpagophytum procumbens, Biosearch Life, Granada, Spain) extracts, the suspension was carried out in DPBS.

\section{Culture cells and treatments}

Human synoviocytes were recovered from the hip synovial membrane of 6 patients undergoing hip replacement surgery (age mean $=75$ years). The cells were released by digestion of the synovial membrane with type I collagenase ( $2 \mathrm{mg} / \mathrm{ml}, 12$ hours; ThermoFisher, Waltham, USA). The cells were incubated in Dulbecco's modified Eagle medium high glucose with glutamine and sodium pyruvate (DMEM, Dutscher), supplemented with 10\% Fetal Bovine Serum (FBS, Dutscher), penicillin-streptomycin (Lonza) then incubated at $37^{\circ} \mathrm{C}$ in a humid atmosphere, containing $5 \% \mathrm{CO} 2$.

To achieve the desired number of cells, passages were performed. The cells were rinsed with DPBS, then detached with $0.05 \%$ trypsin (ThermoFisher). The cells were recovered in culture medium and seeded at approximately 7500 cells $/ \mathrm{cm}^{2}$. The absence of mycoplasmas were checked by PCR.

The cells were processed at confluence. Treatments were diluted in new culture medium to the desired concentration. Each molecule was tested alone or in the presence of LPS. The three molecules were also tested together in order to see the effects of the combination of these three extracts, in the presence or not of LPS.

\section{Protein extraction}

Cells were lysed and protein extracted using Radio Immuno Precipitation Assay (RIPA) Buffer (50mM Tris$\mathrm{HCl} \mathrm{pH} 7.5 ; 1 \%$ Igepal CA-630; $150 \mathrm{mM} \mathrm{NaCl} ; 1 \mathrm{mM}$ EGTA ; $1 \mathrm{mM} \mathrm{NaF} ; 0.25 \%$ Na-deoxycholate ; Distilled water) supplemented with protease inhibitor (Leupeptine $1 \mathrm{mg} / \mathrm{ml}$; Phenyl methyl sulfonyl fluoride $200 \mathrm{mM}$; pepstatin $\mathrm{A} 1 \mathrm{mg} / \mathrm{ml}$ ) and phosphatase inhibitor (sodium orthovanadate $200 \mathrm{mM}$ ) as previously described [26].

\section{Proteomic experiment}

Five $\mu \mathrm{g}$ of each protein extract were prepared using a modified Gel-aided Sample Preparation protocol [27]. Samples were digested with trypsin/Lys-C overnight at $37^{\circ} \mathrm{C}$. For nano-LC fragmentation, protein or peptide samples were first desalted and concentrated onto a $\mu \mathrm{C} 18$ Omix (Agilent) before analysis.

The chromatography step was performed on a NanoElute (Bruker Daltonics) ultra-high-pressure nano flow chromatography system. Approximatively $200 \mathrm{ng}$ of each peptide sample were concentrated onto a C18 pepmap $100\left(5 \mathrm{~mm} \times 300 \mu \mathrm{m}\right.$ i.d.) precolumn (Thermo Scientific) and separated at $50^{\circ} \mathrm{C}$ onto a reversed phase Reprosil column $(25 \mathrm{~cm} \times 75 \mu \mathrm{m}$ i.d.) packed with $1.6 \mu \mathrm{m}$ C18 coated porous silica beads (lonopticks). Mobile phases consisted of $0.1 \%$ formic acid, $99.9 \%$ water $(v / v)(A)$ and $0.1 \%$ formic acid in $99.9 \% \mathrm{ACN}(\mathrm{v} / \mathrm{v})(\mathrm{B})$. The nanoflow rate was set at $400 \mathrm{nl} / \mathrm{min}$, and the gradient profile was as follows: 
from 2 to $15 \%$ B within 60 min, followed by an increase to $25 \%$ B within 30 min and further to $37 \%$ within $10 \mathrm{~min}$, followed by a washing step at $95 \% \mathrm{~B}$ and reequilibration.

MS experiments were carried out on an TIMS-TOF pro mass spectrometer (Bruker Daltonics) with a modified nano electrospray ion source (CaptiveSpray, Bruker Daltonics). The system was calibrated each week and mass precision was better than $1 \mathrm{ppm}$. A 1600 spray voltage with a capillary temperature of $180^{\circ} \mathrm{C}$ was typically employed for ionizing. MS spectra were acquired in the positive mode in the mass range from 100 to $1700 \mathrm{~m} / \mathrm{z}$. In the experiments described here, the mass spectrometer was operated in PASEF mode with exclusion of single charged peptides. A number of 10 PASEF MS/MS scans was performed during 1.25 seconds from charge range $2-5$.

Before post-process, the samples are analysed using Preview software (ProteinMetrics) in order to estimate the quality of the tryptic digestion and predict the post-translational modifications present. The result, below, is used for the "bank research / identification" part. The fragmentation pattern was used to determine the sequence of the peptide. Database searching was performed using the Peaks $X+$ software. A UniProt Homo sapiens database (October 2020) was used. The variable modifications allowed were as follows: Nterm-acetylation, methionine oxidation, Deamidation (NQ), Methylation (KR) and Carbamylation. In addition, C-Propionoamide was set as fix modification. "Trypsin" was selected as Specific. Mass accuracy was set to $30 \mathrm{ppm}$ and $0.05 \mathrm{Da}$ for MS and MS/MS mode, respectively. Data were filtering according to a FDR of $0.5 \%$ and the elimination of protein redundancy on the basis of proteins being evidenced by the same set or a subset of peptides.

\section{Identification of differentially expressed proteins}

To quantify the relative levels of protein abundance between different groups, samples were analysed using the label-free quantification feature of PEAKS X + software. Feature detection was separately performed on each sample by the expectation-maximization based algorithm. The features of the same peptide from all replicates of each sample were aligned through the retention time alignment algorithms. Mass error tolerance was set at $30 \mathrm{ppm}$, Ion Mobility Tolerance (1/k0) at 0.07 and retention time tolerance at $10 \mathrm{~min}$. Normalization factors of the samples were obtained by the total ion current (TIC) of each sample. Quantification of the protein abundance level was calculated using the sum area of the top three unique peptides. A 1.5 -fold increase in relative abundance and a significance $\geq 5$ using ANOVA as significance method were used to determine those enriched proteins

\section{Enrichment analysis et comparison with datasets related to skeletal biology}

Heatmap was performed with a Spearman clustering method using ComplexHeatmap package from R.

Enrichments in molecular process, cellular process and pathways (KEGG and Reactome) were performed using ClueGo App from Cytoscape software. Network specificity was set to medium; GO tree interval was set between 2 and 4 . Clusters were performed using a selection set to 3 min genes in addition to $4 \%$ of genes. Enrichments were performed using a Bonferroni step dowm method. 
Additionally, differentially expressed proteins were compared to existing gene expression datasets related to skeletal biology using SkeletalVis application (http://skeletalvis.ncl.ac.uk/skeletal/, [28]). Proteins encoded by genes associated with osteoarthritis joint damage in animals were also identified using OATargets databases [29].

\section{RNA extraction and RT-PCR}

RNA was extracted from the cell layer using the kit RNeasy mini kit (Qiagen, Hilden, Germany) according to the supplier's protocol. DNase treatment and the reverse transcription were, then, carried out using the kit DNase I (Sigma Aldrich) and the reverse transcriptase M-MLV (Invitrogen, Carlsbad, USA) as previously described [30]. Next, cDNA was amplifed by real-time PCR using PCR master Mix (Power Syber Green, Applied biosystems, Courtaboeuf, France) and read on Step One Plus Real Time PCR system (Applied Biosystems) with the following primers: RPL13A Forward: 5'-GAGGTATGCTGCCCCACAAA-3' and Reversed: 5'-GTGGGATGCCGTCAAACAC-3'; NGF Forward: 5'-AGCGCAGCGAGTTTTGG-3' and Reversed: 5'AGAAAGCTGCTCCCTTGGTA-3'; IL-6 Forward: 5'-CACACAGACAGCCACTCACC-3' and Reversed : 5'TTTCACCAGGCAAGTCTCCT-3'; MMP1 Forward: 5'-GAAGCTGCTTACGAATTTGCCG-3' and Reversed: 5'CCAAAGGAGCTGTAGATGTCCT-3'; MMP3 Forward: 5'-TAAAGACAGGCACTT TTGGCGC-3' and Reversed: 5'-TTGGGTATCCAGCTCGTACCTC-3'; MMP13 Forward: 5'-AAGGAGCATGGCGACTTCT-3' and Reversed: 5'TGGCCCAGGAGGAAAAGC-3'. The relative mRNA level was calculated with the $2^{-\triangle \triangle C T}$ method. RPL13a was used as the invariant housekeeping gene internal control. The choice of this gene is based on our previously experience on the field.

\section{ELISA}

PGE2 and MMP release into conditioned media was quantified using commercially available enzyme immunoassay kit (R\&D Biosystem) as previously [26]. For IL-6, we proceeded in the same way but using the Human beta-NGF ELISA Kit and Human IL-6 ELISA kit (Sigma Aldrich). The immunoassays were all carried out following manufacturer protocol. Absorbance was determined at $450 \mathrm{~nm}$ with a wavelength correction set at $540 \mathrm{~nm}$ using Multiskan GO spectrophotometer (Thermo Scientific).

\section{Statistical analyses}

All results are expressed as the mean of 3 or 4 patients (biological replicats) \pm standard error of the mean (SEM). Statistical analyzes are carried out on GraphPad prism 8 software. After checking the normal distribution of samples, two-way ANOVA's tests were used for multiple comparisons. In significant cases, Tukey's multiple comparisons test for matched samples were performed as post-hoc analysis. P-values < 0.05 were considered significant.

\section{Results}

Stimulation of human OA synovial cells with LPS, an efficient OA model in vitro. 
Lipopolysaccharide (LPS) is recently considered as a trigger for the pathology of OA, and is used to model inflammatory component of OA. So, we planned to test the effects of curcumin, harpagophytum and bromelain in human OA synovial cells stimulated with LPS. Before, we wanted to validate the model and its ability to model OA inflammation. So, we did proteomic analysis to define differential expressed proteins between unstimulated OA synovial cells and LPS-stimulated OA synovial cells. 2917 proteins were identified in the control group, and 3011 in the LPS treated-group. Among them, 106 proteins were differentially expressed between the two groups (Peaks Sign $>5$, Fold-change $>1.5$, figure 1 and table 1 ). More precisely, 66 proteins (i.e. $62 \%$ ) were significantly downregulated by LPS, and 40 (i.e. $38 \%$ ) were upregulated by LPS. ClueGo analysis revealed that these differentially expressed proteins are mainly involved in the biological processes of oxidative stress-induced cell death $(45 \%$, p-value $<0.01)$ and in the molecular processes of intramolecular oxidoreductase activity $(25 \%$, p-value $<0.01)$ and collagen binding $(12.5 \%$, p-value $<0.01$ ) (figures 2, tables 2 and 3). Furthermore, pathway enrichment by KEGG (figure 3A, table 4) showed the presence of proteins involved in protein digestion and absorption, fructose and mannose metabolism and antigen processing and presentation ( $33 \%$ for each, $p$-value $<0.01$ ).

Enrichment using Reactome (figure 3B, table 5) shows also the presence of proteins involved in assembly of collagen fibrils and other multimeric structures $(24 \%$, $p$-value $<0.05)$.

The comparison by signature of the proteomic profile between control and LPS stimulated synovial cells using skeletalvis database, which permits to explore skeletal biology related expression datasets [28], suggests that deregulated proteins were encoded by genes which are also differentially expressed in several other OA models (suppl data 1), namely "Synovial cells from inflammatory and normal areas of osteoarthritis synovial membrane" (signed jaccard $(\mathrm{sig})=0.015$; zscore $=5.08$ ) and observed in "Rat model of surgically induced knee osteoarthritis" (signed jaccard $(\mathrm{sig})=0.0118$; zscore $=3.98$ ). Besides, using OATargets databases [29], we could observe that several identified proteins were encoded by genes associated to OA, such as Thrombpondin-1 (THBS1), collagen alpha-1(VI) chain (COL6A1), superoxide dismutase [Mn] mitochondrial (SOD2) and Nicotinamide phosphoribyltransferase (NAMPT) (table 1). In addition, about half of these gene was also found at least once as a human OA DEG, and around $90 \%$ are known to interact with OA genes (table 1).

Together this proteomic analysis clearly confirms that LPS-stimulated synovial cells from OA human patients are good model to study osteoarthritis process in vitro.

\section{LPS increases the expression of genes associated to inflammation, catabolism and pain}

Next, using a most targeted strategy, we investigated the effect of LPS treatment in human OA synovial cells. After 24 hours of treatment, LPS stimulated inflammation through the production of proinflammatory cytokines (Interleukin-6, IL-6), the catabolism through an increase of metalloproteases (MMP-1, MMP-3, MMP-13), and the production of pain-mediating neurotrophin (Nerve Growth Factor, NGF). These increases were observed at level of mRNA levels and of protein release. LPS also increased the amount of PGE2, another pain mediator (figure 4). 


\section{The association of curcumin with bromelain and harpagophytum significantly reduced the LPS-induced expression of genes associated to catabolism}

Having validated our model, we continued by studying the effect of vegetal extracts (curcumin bromelain, and harpagophytum) on OA associated genes. At doses tested, vegetal extracts had little effects on the expression of catabolic genes. Only curcumin slightly counteracted the effects of LPS on MMP13 mRNA and protein release. However, the association of curcumin with harpagophytum and bromelain reversed effects of LPS on the mRNA levels of MMP1, MMP3 and MMP13, and on the release of MMP3 and MMP13 proteins (figure 5). These data suggest that the combination of curcumin, bromelain and harpagophytum may reduce cartilage degradation during OA process.

\section{The association of curcumin with bromelain and harpagophytum significantly reduced the LPS-induced expression of genes associated to inflammation and pain}

Next, we investigated the effect of these vegetal compounds on the expression of genes involved in inflammation and pain (figure 6). We observed that only curcumin was able to slighty reduce the LPSinduced expression of NGF and the release of PGE2 and IL-6. Interestingly, the association of the three vegetal compounds (curcumin, harpagophytum and bromelain) significantly reduced the gene expression of IL-6 and NGF mRNA expression. It also decreases the IL-6 release and the production of PGE2. This suggest that the combination of the three compound may reduce inflammation and pain.

\section{Discussion}

To date, no efficient treatment exists to treat osteoarthritis. Consequently, the identification of strategies able to slow down OA progression and usable in the long term is crucial. Some natural compounds are known to present anti-oxidative and anti-inflammatory actions. So, they may be an alternative to pharmacological drugs. Herein, after a proteomic characterization of the in vitro OA model which was used in the study and validation that it is able to induce changes in gene expression profile similar to that is observed during $O A$, we showed that the combination of curcumin, harpagophytum and bromelain is efficient to counteract numerous LPS-induced effects in human OA synovial cells.

First, we evaluate the potential of lipopolysaccharide to induce changes in gene/protein expression mimicking some features of OA. LPS is an endotoxin and a classical activator of the innate immune system. Because of its pathophysiological properties, LPS has been used to induce arthritis in conjunction with collagen in animal models [31,32]. More recently, researchers have started to connect LPS with the pathogenesis of OA [33]. LPS is released by gut microbiota and is correlated with the pathophysiology of osteoarthritis, in part through the activation of macrophages. In addition, local LPS administration to joints induce synovitis and is used as a model to evaluate potential treatments for acute synovitis [34]..

Since LPS is now considered as a trigger for the pathology of OA, especially by activating synovial cells, we have proposed that stimulated human OA synovial cells may induce inflammation and reproduce in 
vitro some changes observed during OA process. Using proteomics, we demonstrate here that treatment of human OA synovial cells with LPS induces the expression of signature genes of OA, and in particular reproduces some gene expression changes observed in synovial cells from inflammatory and normal areas of osteoarthritis synovial membrane. A more targeted strategy shows for instance that LPS induces the expression of MMPs, IL-6, PGE2 and NGF, which are mainly markers of catabolism, inflammation and pain in joints. Consequently, the stimulation of human OA synovial cells by LPS appears a good in vitro model to study inflammation during OA. Knowing that alleviating inflammation may prevent the onset or minimize the progression of $\mathrm{OA}[2,11,12,33]$, we propose to use this in vitro model to test the ability of several natural substances to reduce inflammation.

First, we show that curcumin have some anti-catabolic and anti-inflammatory action in human OA synovial cells. This is in agreement with literature which demonstrate that curcumin reduces MMP-3 and MMP-13 expression in rabbit chondrocytes and in the articular cartilage of estrogen-deficient rats, preventing collagen degradation $[35,36]$. Also, curcumin prevents the activation of nuclear factor kappaB (NF-KB), the major mediator of inflammation [36, 37]. Another study shows that curcumin favors cartilage anabolism by increasing type II collagen synthesis $[22,38]$.

We also investigated the effect of Harpagophytum, commonly known as devil's claw, a plant used worldwide as a traditional remedy for joint pain associated with $O A$ and mild rheumatic ailments [25, 39, 40]. Moreover, it has been described to have analgesic effects on neuropathic pain in rats [41]. We also studied the effect of bromelain, a food supplement that is sometimes describes as an alternative treatment to nonsteroidal anti-inflammatory drug (NSAIDs) [42]. Bromelain has analgesic properties [43, 44] and relieves OA [24]. However, at dose tested, neither Harpogophytum nor bromolain show significant effect on the expression of studied genes, including NGF or PGE2, which are known to be related to joint pain. However, the association of these vegetal components with curcumin permits to counteract numerous effect of LPS in human OA stimulated cells. The combination of curcumin with bromelain and harpagophytum significantly reduced the LPS-induced expression of genes associated to inflammation and pain, but also catabolism. This reinforced action of curcumin by combination with other natural compounds was already described [15]. For instance, the combination treatment with Lactobacillus acidophilus LA-1, vitamin B, and curcumin ameliorates the progression of osteoarthritis by inhibiting the pro-inflammatory mediators [23]. However, at our knowledge, this paper is the first to show the benefice to associated curcumin with bromelain and Harpagophytum.

In conclusion, we describe the changes in protein expression induced by LPS in human OA synovial cells and demonstrating that they are characteristic to inflamed OA synoviocytes, suggesting that this in vitro model may be useful to evaluate inflammation during $O A$. In addition, we showing that the combination of three natural vegetal components reduced expression of genes involved in catabolism, inflammation and pain, suggesting that together, they may present a beneficial effect on OA patients by alleviating OA pain and synovial inflammation, and reducing cartilage degradation.

\section{Declarations}




\section{Ethics approval and consent to participate}

The experimental protocol was approved by the local ethical committee "Comité de Protection des Personnes Nord-Ouest III" (agreement \# A13-D46-VOL.19). The consent of each participant was obtained prior to surgery. They all signed agreement forms, in accordance with local law. All methods were performed in accordance with the relevant guidelines and regulations.

\section{Consent for publication}

Not applicable

\section{Availability of data and materials}

The datasets supporting the conclusions of this article are included within the article and its additional file.

\section{Competing interests}

Thierry Conrozier received fees from LABRHA for scientific consultant and speaker services.

The other authors declare that they have no competing interests.

\section{Funding}

This study was founded from Labhra laboratory, which supplied also vegetal compounds. The funding lab had no role in the study design, data collection and analysis, decision to publish, or preparation of the manuscript.

\section{Authors' contributions}

CB participated in the conception, design of the study, analysis of data and drafted the manuscript. SB carried out the experiments and analysis data. BB and JP did proteomic experiments and analysis. TC participated to the coordination and conception of the study and design. KB participated in the conception and design of the study and helped to draft the manuscript. All authors read and approved the final manuscript.

\section{Acknowledgments}

The authors thank Sylvain Leclercq and collaborators (Clinique Saint-Martin, Caen, France) for gift of synovial tissues.

\section{References}

1. Malemud CJ. Biologic basis of osteoarthritis: state of the evidence. Curr Opin Rheumatol. 2015;27:289-94. 
2. Berenbaum F. Osteoarthritis as an inflammatory disease (osteoarthritis is not osteoarthrosis!). Osteoarthritis Cartilage. 2013;21:16-21.

3. Neogi T. The epidemiology and impact of pain in osteoarthritis. Osteoarthritis Cartilage. 2013;21:1145-53.

4. Robinson $W H$, Lepus $C M$, Wang $Q$, Raghu $H$, Mao R, Lindstrom $T M$, et al. Low-grade inflammation as a key mediator of the pathogenesis of osteoarthritis. Nat Rev Rheumatol. 2016;12:580-92.

5. Bigoni M, Sacerdote P, Turati M, Franchi S, Gandolla M, Gaddi D, et al. Acute and late changes in intraarticular cytokine levels following anterior cruciate ligament injury. J Orthop Res Off Publ Orthop Res Soc. 2013;31:315-21.

6. Kapoor M, Martel-Pelletier J, Lajeunesse D, Pelletier J-P, Fahmi H. Role of proinflammatory cytokines in the pathophysiology of osteoarthritis. Nat Rev Rheumatol. 2011;7:33-42.

7. Scotece M, Conde J, Abella V, López V, Francisco V, Ruiz C, et al. Oleocanthal Inhibits Catabolic and Inflammatory Mediators in LPS-Activated Human Primary Osteoarthritis (OA) Chondrocytes Through MAPKs/NF-kB Pathways. Cell Physiol Biochem Int J Exp Cell Physiol Biochem Pharmacol. 2018;49:2414-26.

8. Konttinen YT, Sillat T, Barreto G, Ainola M, Nordström DCE. Osteoarthritis as an autoinflammatory disease caused by chondrocyte-mediated inflammatory responses. Arthritis Rheum. 2012;64:613-6.

9. Xiao Y, Ding L, Yin S, Huang Z, Zhang L, Mei W, et al. Relationship between the pyroptosis of fibroblast-like synoviocytes and HMGB1 secretion in knee osteoarthritis. Mol Med Rep. 2021;23:1.

10. Santangelo KS, Nuovo GJ, Bertone AL. In vivo reduction or blockade of interleukin-1 $\beta$ in primary osteoarthritis influences expression of mediators implicated in pathogenesis. Osteoarthritis Cartilage. 2012;20:1610-8.

11. Griffin TM, Huebner JL, Kraus VB, Yan Z, Guilak F. Induction of osteoarthritis and metabolic inflammation by a very high-fat diet in mice: effects of short-term exercise. Arthritis Rheum. 2012;64:443-53.

12. Huang Z, Kraus VB. Does lipopolysaccharide-mediated inflammation have a role in OA? Nat Rev Rheumatol. 2016;12:123-9.

13. Li K, Liu A, Zong W, Dai L, Liu Y, Luo R, et al. Moderate exercise ameliorates osteoarthritis by reducing lipopolysaccharides from gut microbiota in mice. Saudi J Biol Sci. 2021;28:40-9.

14. Tabas I, Glass CK. Anti-inflammatory therapy in chronic disease: challenges and opportunities. Science. 2013;339:166-72.

15. Hosseini-Zare MS, Sarhadi M, Zarei M, Thilagavathi R, Selvam C. Synergistic effects of curcumin and its analogs with other bioactive compounds: A comprehensive review. Eur J Med Chem. 2021;210:113072.

16. Henrotin Y, Malaise M, Wittoek R, de Vlam K, Brasseur J-P, Luyten FP, et al. Bio-optimized Curcuma longa extract is efficient on knee osteoarthritis pain: a double-blind multicenter randomized placebo controlled three-arm study. Arthritis Res Ther. 2019;21. doi:10.1186/s13075-019-1960-5. 
17. Madhu K, Chanda K, Saji MJ. Safety and efficacy of Curcuma longa extract in the treatment of painful knee osteoarthritis: a randomized placebo-controlled trial. Inflammopharmacology. 2013;21:129-36.

18. Atabaki M, Shariati-Sarabi Z, Tavakkol-Afshari J, Mohammadi M. Significant immunomodulatory properties of curcumin in patients with osteoarthritis; a successful clinical trial in Iran. Int Immunopharmacol. 2020;85:106607.

19. Nakagawa Y, Mukai S, Yamada S, Murata S, Yabumoto H, Maeda T, et al. The Efficacy and Safety of Highly-Bioavailable Curcumin for Treating Knee Osteoarthritis: A 6-Month Open-Labeled Prospective Study. Clin Med Insights Arthritis Musculoskelet Disord. 2020;13:1179544120948471.

20. Belcaro G, Cesarone MR, Dugall M, Pellegrini L, Ledda A, Grossi MG, et al. Efficacy and safety of Meriva ${ }^{\circledR}$, a curcumin-phosphatidylcholine complex, during extended administration in osteoarthritis patients. Altern Med Rev J Clin Ther. 2010;15:337-44.

21. Yeh C-C, Su Y-H, Lin Y-J, Chen P-J, Shi C-S, Chen C-N, et al. Evaluation of the protective effects of curcuminoid (curcumin and bisdemethoxycurcumin)-loaded liposomes against bone turnover in a cell-based model of osteoarthritis. Drug Des Devel Ther. 2015;9:2285-300.

22. Nicoliche T, Maldonado DC, Faber J, Silva MCP da. Evaluation of the articular cartilage in the knees of rats with induced arthritis treated with curcumin. PloS One. 2020;15:e0230228.

23. Jhun J, Min H-K, Na HS, Kwon JY, Ryu J, Cho K-H, et al. Combinatmarion treatment with Lactobacillus acidophilus LA-1, vitamin $B$, and curcumin ameliorates the progression of osteoarthritis by inhibiting the pro-inflammatory mediators. Immunol Lett. 2020;228:112-21.

24. Pavan R, Jain S, Shraddha null, Kumar A. Properties and therapeutic application of bromelain: a review. Biotechnol Res Int. 2012;2012:976203.

25. Mariano A, Di Sotto A, Leopizzi M, Garzoli S, Di Maio V, Gullì M, et al. Antiarthritic Effects of a Root Extract from Harpagophytum procumbens DC: Novel Insights into the Molecular Mechanisms and Possible Bioactive Phytochemicals. Nutrients. 2020;12.

26. Allas L, Brochard S, Rochoux Q, Ribet J, Dujarrier C, Veyssiere A, et al. EZH2 inhibition reduces cartilage loss and functional impairment related to osteoarthritis. Sci Rep. 2020;10:19577.

27. Fischer R, Kessler BM. Gel-aided sample preparation (GASP) - A simplified method for gel-assisted proteomic sample generation from protein extracts and intact cells. Proteomics. 2015;15:1224-9.

28. Soul J, Hardingham TE, Boot-Handford RP, Schwartz J-M. SkeletalVis: an exploration and metaanalysis data portal of cross-species skeletal transcriptomics data. Bioinformatics. 2019;35:228390.

29. Soul J, Barter MJ, Little CB, Young DA. OATargets: a knowledge base of genes associated with osteoarthritis joint damage in animals. Ann Rheum Dis. 2021;80:376-83.

30. Allas L, Rochoux Q, Leclercq S, Boumédiene K, Baugé C. Development of a simple osteoarthritis model useful to predict in vitro the anti-hypertrophic action of drugs. Lab Investig J Tech Methods Pathol. 2020;100:64-71. 
31. Lorenz W, Buhrmann C, Mobasheri A, Lueders C, Shakibaei M. Bacterial lipopolysaccharides form procollagen-endotoxin complexes that trigger cartilage inflammation and degeneration: implications for the development of rheumatoid arthritis. Arthritis Res Ther. 2013;15:R111.

32. Caccese RG, Zimmerman JL, Carlson RP. Bacterial lipopolysaccharide potentiates type II collageninduced arthritis in mice. Mediators Inflamm. 1992;1:273-9.

33. Huang ZY, Stabler T, Pei FX, Kraus VB. Both systemic and local lipopolysaccharide (LPS) burden are associated with knee OA severity and inflammation. Osteoarthritis Cartilage. 2016;24:1769-75.

34. Mendez ME, Sebastian A, Murugesh DK, Hum NR, McCool JL, Hsia AW, et al. LPS-Induced Inflammation Prior to Injury Exacerbates the Development of Post-Traumatic Osteoarthritis in Mice. J Bone Miner Res Off J Am Soc Bone Miner Res. 2020;35:2229-41.

35. Park S, Lee LR, Seo JH, Kang S. Curcumin and tetrahydrocurcumin both prevent osteoarthritis symptoms and decrease the expressions of pro-inflammatory cytokines in estrogen-deficient rats. Genes Nutr. 2016;11:2.

36. Yang Q, Wu S, Mao X, Wang W, Tai H. Inhibition effect of curcumin on TNF-a and MMP-13 expression induced by advanced glycation end products in chondrocytes. Pharmacology. 2013;91:77-85.

37. Kumar D, Kumar M, Saravanan C, Singh SK. Curcumin: a potential candidate for matrix metalloproteinase inhibitors. Expert Opin Ther Targets. 2012;16:959-72.

38. Zhao P, Cheng J, Geng J, Yang M, Zhang Y, Zhang Q, et al. Curcumin protects rabbit articular chondrocytes against sodium nitroprusside-induced apoptosis in vitro. Eur J Pharmacol. 2018;828:146-53.

39. Dragos D, Gilca M, Gaman L, Vlad A, losif L, Stoian I, et al. Phytomedicine in Joint Disorders. Nutrients. 2017;9.

40. Gagnier JJ, Chrubasik S, Manheimer E. Harpgophytum procumbens for osteoarthritis and low back pain: a systematic review. BMC Complement Altern Med. 2004;4:13.

41. Lim DW, Kim JG, Han D, Kim YT. Analgesic effect of Harpagophytum procumbens on postoperative and neuropathic pain in rats. Mol Basel Switz. 2014;19:1060-8.

42. Brien S, Lewith G, Walker A, Hicks SM, Middleton D. Bromelain as a Treatment for Osteoarthritis: a Review of Clinical Studies. Evid-Based Complement Altern Med ECAM. 2004;1:251-7.

43. Cohen A, Goldman J. BROMELAINS THERAPY IN RHEUMATOID ARTHRITIS. Pa Med J 1928. 1964;67:27-30.

44. Kumakura S, Yamashita M, Tsurufuji S. Effect of bromelain on kaolin-induced inflammation in rats. Eur J Pharmacol. 1988;150:295-301.

\section{Tables}

Table 1: List of deregulated proteins in LPS-stimulated synovial cells 


\begin{tabular}{|c|c|c|c|c|c|c|c|c|c|}
\hline Accession & $\begin{array}{l}\text { Group } \\
\text { Profile } \\
\text { (Ratio) }\end{array}$ & $\begin{array}{l}\text { Gene } \\
\text { names } \\
\text { (primary ) }\end{array}$ & Description & $\begin{array}{l}\text { OA } \\
\text { associated }\end{array}$ & $\begin{array}{l}\text { human } \\
\text { OA } \\
\text { DEG }\end{array}$ & $\begin{array}{l}\text { n induc } \\
\text { OA } \\
\text { DEG }\end{array}$ & & $\begin{array}{l}\text { OA gene } \\
\text { interaction }\end{array}$ & $\begin{array}{l}\text { skeletal } \\
\text { phenotype }\end{array}$ \\
\hline \multicolumn{10}{|c|}{$\begin{array}{l}\text { Proteins down-regulated by } \\
\text { LPS }\end{array}$} \\
\hline Q92598 & 0.23 & HSPH1 & Heat shock protein $105 \mathrm{kDa}$ & false & & 2 & 8 & 14 & false \\
\hline P49327 & 0.25 & FASN & Fatty acid synthase & false & & 3 & 7 & 17 & false \\
\hline Q9Y3C0 & 0.26 & WASHC3 & WASH complex subunit 3 & false & & 1 & 1 & 3 & false \\
\hline Q9H4B7 & 0.32 & TUBB1 & Tubulin beta-1 chain & false & & 5 & 1 & 3 & false \\
\hline P45877 & 0.36 & PPIC & $\begin{array}{l}\text { Peptidyl-prolyl cis-trans } \\
\text { isomerase C }\end{array}$ & false & & 8 & 9 & 0 & false \\
\hline Q12768 & 0.43 & WASHC5 & WASH complex subunit 5 & false & & 0 & 0 & 2 & false \\
\hline P07996 & 0.45 & THBS1 & Thrombpondin-1 & true & & 4 & 2 & 19 & true \\
\hline Q8WWI1 & 0.45 & LMO7 & LIM domain only protein 7 & false & & 3 & 5 & 7 & false \\
\hline Q8WX93 & 0.47 & PALLD & Palladin & false & & 3 & 2 & 5 & false \\
\hline Q8NHP8 & 0.48 & PLBD2 & Putative phpholipase B-like 2 & false & & 0 & 0 & 2 & false \\
\hline Q8NE86 & 0.49 & $\mathrm{MCU}$ & $\begin{array}{l}\text { Calcium uniporter protein } \\
\text { mitochondrial }\end{array}$ & false & & 0 & 0 & 0 & false \\
\hline O60831 & 0.51 & PRAF2 & PRA1 family protein 2 & false & & 1 & 3 & 0 & false \\
\hline Q9UMX0 & 0.52 & UBQLN1 & Ubiquilin-1 & false & & 1 & 1 & 15 & false \\
\hline Q9NR12 & 0.52 & PDLIM7 & $\begin{array}{l}\text { PDZ and LIM domain protein } \\
7\end{array}$ & false & & 5 & 3 & 7 & false \\
\hline O00154 & 0.52 & ACOT7 & $\begin{array}{l}\text { Cytolic acyl coenzyme A } \\
\text { thioester hydrolase }\end{array}$ & false & & 0 & 3 & 1 & false \\
\hline Q9Y305 & 0.53 & АCOT9 & $\begin{array}{l}\text { Acyl-coenzyme A thioesterase } \\
9 \text { mitochondrial }\end{array}$ & false & & 0 & 4 & 6 & false \\
\hline Q71U36 & 0.53 & TUBA1A & Tubulin alpha-1A chain & false & 1 & 1 & 1 & 31 & false \\
\hline P15374 & 0.53 & UCHL3 & $\begin{array}{l}\text { Ubiquitin carboxyl-terminal } \\
\text { hydrolase isozyme L3 }\end{array}$ & false & 0 & 0 & 7 & 5 & false \\
\hline Q04760 & 0.53 & GLO1 & Lactoylglutathione lyase & false & 0 & 0 & 3 & 3 & true \\
\hline P30419 & 0.53 & NMT1 & $\begin{array}{l}\text { Glycylpeptide } \mathrm{N} \text { - } \\
\text { tetradecanoyltransferase } 1\end{array}$ & false & 1 & 1 & 1 & 4 & false \\
\hline P55809 & 0.54 & OXCT1 & $\begin{array}{l}\text { Succinyl-CoA:3-ketoacid } \\
\text { coenzyme A transferase } 1 \\
\text { mitochondrial }\end{array}$ & false & 2 & 2 & 4 & 3 & false \\
\hline O43504 & 0.55 & LAMTOR5 & $\begin{array}{l}\text { Ragulator complex protein } \\
\text { LAMTOR5 }\end{array}$ & false & 0 & 0 & 1 & 4 & false \\
\hline P62841 & 0.55 & RPS15 & 40S ribomal protein S15 & false & 1 & 1 & 5 & 9 & false \\
\hline P36776 & 0.55 & LONP1 & $\begin{array}{l}\text { Lon protease homolog } \\
\text { mitochondrial }\end{array}$ & false & 4 & 4 & 3 & 7 & false \\
\hline Q12849 & 0.55 & GRSF1 & G-rich sequence factor 1 & false & 0 & 0 & 1 & 2 & false \\
\hline Q5JRX3 & 0.55 & PITRM1 & $\begin{array}{l}\text { Presequence protease } \\
\text { mitochondrial }\end{array}$ & false & 2 & 2 & 3 & 2 & false \\
\hline Q8TDQ7 & 0.55 & GNPDA2 & $\begin{array}{l}\text { Glucamine-6-phphate } \\
\text { isomerase } 2\end{array}$ & false & 0 & 0 & 1 & 1 & false \\
\hline P34932 & 0.56 & HSPA4 & Heat shock $70 \mathrm{kDa}$ protein 4 & false & 0 & 0 & 2 & 39 & false \\
\hline Q15691 & 0.56 & MAPRE1 & $\begin{array}{l}\text { Microtubule-associated } \\
\text { protein RP/EB family member } \\
1\end{array}$ & false & 0 & 0 & 0 & 13 & false \\
\hline P24539 & 0.56 & АТР5РB & $\begin{array}{l}\text { ATP synthase } \mathrm{F}(0) \text { complex } \\
\text { subunit B1 mitochondrial }\end{array}$ & false & 0 & 0 & 0 & 6 & false \\
\hline P00491 & 0.56 & PNP & Purine nucleide phphorylase & false & 6 & 6 & 3 & 1 & false \\
\hline
\end{tabular}




\begin{tabular}{|c|c|c|c|c|c|c|c|}
\hline P69905 & 0.56 & $\begin{array}{l}\text { HBA1; } \\
\text { HBA2 }\end{array}$ & Hemoglobin subunit alpha & false & 7 & 0 & 3 false \\
\hline Q15008 & 0.57 & PSMD6 & $\begin{array}{l}26 \mathrm{~S} \text { proteasome non-ATPase } \\
\text { regulatory subunit } 6\end{array}$ & false & 0 & 5 & 4 false \\
\hline P02768 & 0.57 & ALB & Albumin & false & 2 & 0 & 9 false \\
\hline Q9UHB6 & 0.57 & LIMA1 & $\begin{array}{l}\text { LIM domain and actin- } \\
\text { binding protein } 1\end{array}$ & false & 2 & 4 & 9 true \\
\hline Q15843 & 0.57 & NEDD8 & NEDD8 & false & 0 & 3 & 9 false \\
\hline P15848 & 0.58 & ARSB & Arylsulfatase B & false & 3 & 6 & 1 true \\
\hline O95202 & 0.58 & LETM1 & $\begin{array}{l}\text { Mitochondrial proton/calcium } \\
\text { exchanger protein }\end{array}$ & false & 0 & 2 & 3 false \\
\hline P12109 & 0.59 & COL6A1 & Collagen alpha-1(VI) chain & true & 6 & 12 & 9 false \\
\hline Q9UNZ2 & 0.59 & NSFL1C & NSFL1 cofactor p47 & false & 0 & 1 & 8 false \\
\hline Q9Y5L4 & 0.59 & TIMM13 & $\begin{array}{l}\text { Mitochondrial import inner } \\
\text { membrane translocase } \\
\text { subunit Tim13 }\end{array}$ & false & 0 & 3 & 3 false \\
\hline P55795 & 0.61 & HNRNPH2 & $\begin{array}{l}\text { Heterogeneous nuclear } \\
\text { ribonucleoprotein H2 }\end{array}$ & false & 0 & 2 & 5 true \\
\hline Q9H008 & 0.61 & LHPP & $\begin{array}{l}\text { Phpholysine phphohistidine } \\
\text { inorganic pyrophphate } \\
\text { phphatase }\end{array}$ & false & 4 & 5 & 0 false \\
\hline P12111 & 0.62 & COL6A3 & Collagen alpha-3(VI) chain & false & 6 & 16 & 2 true \\
\hline O14745 & 0.62 & SLC9A3R1 & $\begin{array}{l}\mathrm{Na}(+) / \mathrm{H}(+) \text { exchange } \\
\text { regulatory cofactor NHE-RF1 }\end{array}$ & false & 1 & 4 & 11 true \\
\hline P98179 & 0.62 & RBM3 & RNA-binding protein 3 & false & 1 & 1 & 5 false \\
\hline Q14318 & 0.62 & FKBP8 & $\begin{array}{l}\text { Peptidyl-prolyl cis-trans } \\
\text { isomerase FKBP8 }\end{array}$ & false & 1 & 2 & 10 true \\
\hline O94826 & 0.62 & TOMM70 & $\begin{array}{l}\text { Mitochondrial import } \\
\text { receptor subunit TOM70 }\end{array}$ & false & 0 & 2 & 4 false \\
\hline P48509 & 0.62 & CD151 & CD151 antigen & false & 0 & 1 & 0 false \\
\hline O75348 & 0.62 & ATP6V1G1 & $\begin{array}{l}\text { V-type proton ATPase subunit } \\
\text { G } 1\end{array}$ & false & 1 & 2 & 0 false \\
\hline P60953 & 0.63 & CDC42 & $\begin{array}{l}\text { Cell division control protein } \\
42 \text { homolog }\end{array}$ & true & 0 & 0 & 19 true \\
\hline Q9BRA2 & 0.63 & TXNDC17 & $\begin{array}{l}\text { Thioredoxin domain- } \\
\text { containing protein } 17\end{array}$ & false & 1 & 1 & 0 false \\
\hline Q9BRF8 & 0.63 & CPPED1 & $\begin{array}{l}\text { Serine/threonine-protein } \\
\text { phphatase CPPED1 }\end{array}$ & false & 2 & 0 & 0 false \\
\hline Q07666 & 0.64 & KHDRBS1 & $\begin{array}{l}\text { KH domain-containing RNA- } \\
\text { binding signal } \\
\text { transduction-associated } \\
\text { protein } 1\end{array}$ & false & 0 & 2 & 16 true \\
\hline Q16795 & 0.64 & NDUFA9 & $\begin{array}{l}\text { NADH dehydrogenase } \\
\text { [ubiquinone] } 1 \text { alpha } \\
\text { subcomplex subunit } 9 \\
\text { mitochondrial }\end{array}$ & false & 0 & 2 & 6 false \\
\hline O75431 & 0.64 & MTX2 & Metaxin-2 & false & 0 & 1 & 0 false \\
\hline Q9C0H2 & 0.64 & TTYH3 & Protein tweety homolog 3 & false & 1 & 4 & 0 false \\
\hline Q5JPE7 & 0.64 & NOMO2 & Nodal modulator 2 & false & 0 & 0 & 1 false \\
\hline P69849 & 0.64 & NOMO3 & Nodal modulator 3 & false & 0 & 0 & 1 false \\
\hline P00966 & 0.65 & ASS1 & Argininuccinate synthase & false & 4 & 2 & 4 false \\
\hline O75531 & 0.65 & BANF1 & Barrier-to-autointegration & false & 0 & 2 & 2 false \\
\hline
\end{tabular}


factor

\begin{tabular}{|c|c|c|c|c|c|c|}
\hline 095372 & 0.65 LYPLA2 & Acyl-protein thioesterase 2 & false & 0 & 0 & 1 false \\
\hline Q9P1F3 & 0.65 ABRACL & Ctars family protein ABRACL & false & 3 & 2 & 0 false \\
\hline Q15233 & $0.66 \mathrm{NONO}$ & $\begin{array}{l}\text { Non-POU domain-containing } \\
\text { octamer-binding protein }\end{array}$ & false & 0 & 2 & 16 false \\
\hline P14324 & 0.66 FDPS & $\begin{array}{l}\text { Farnesyl pyrophphate } \\
\text { synthase }\end{array}$ & false & 0 & 2 & 3 false \\
\hline P60983 & 0.66 GMFB & Glia maturation factor beta & false & 1 & 2 & 1 false \\
\hline \multicolumn{7}{|c|}{ Protein up-regulated by LPS } \\
\hline Q96AT9 & $51.49 \mathrm{RPE}$ & $\begin{array}{l}\text { Ribulose-phosphate } 3 \text { - } \\
\text { epimerase }\end{array}$ & false & 0 & 0 & 3 false \\
\hline O14684 & 4.09 PTGES & Prostaglandin E synthase & false & 8 & 4 & 0 false \\
\hline P43490 & 3.35 NAMPT & $\begin{array}{l}\text { Nicotinamide } \\
\text { phphoribyltransferase }\end{array}$ & true & 8 & 0 & 4 false \\
\hline O43776 & 2.66 NARS1 & $\begin{array}{l}\text { Asparagine--tRNA ligase } \\
\text { cytoplasmic }\end{array}$ & false & 0 & 0 & 3 false \\
\hline Q5VYK3 & 2.56 ECPAS & $\begin{array}{l}\text { Proteasome adapter and } \\
\text { scaffold protein ECM29 }\end{array}$ & false & 1 & 0 & 8 false \\
\hline P12955 & 2.47 PEPD & Xaa-Pro dipeptidase & false & 0 & 5 & 5 true \\
\hline P10301 & 2.33 RRAS & Ras-related protein R-Ras & false & 3 & 1 & 5 false \\
\hline P19827 & 2.27 ITIH1 & $\begin{array}{l}\text { Inter-alpha-trypsin inhibitor } \\
\text { heavy chain H1 }\end{array}$ & false & 0 & 1 & 1 false \\
\hline P15121 & 2.04 AKR1B1 & $\begin{array}{l}\text { Aldo-keto reductase family } 1 \\
\text { member B1 }\end{array}$ & false & 0 & 4 & 3 false \\
\hline O14828 & 1.96 SCAMP3 & $\begin{array}{l}\text { Secretory carrier-associated } \\
\text { membrane protein } 3\end{array}$ & false & 1 & 1 & 4 false \\
\hline P07711 & 1.95 CTSL & Cathepsin L1 & false & 4 & 0 & 3 false \\
\hline Q6IBS0 & 1.92 TWF2 & Twinfilin-2 & false & 0 & 5 & 0 false \\
\hline P04179 & 1.9 SOD2 & $\begin{array}{l}\text { Superoxide dismutase }[\mathrm{Mn}] \\
\text { mitochondrial }\end{array}$ & true & 7 & 7 & 8 false \\
\hline P54709 & 1.85 АТР1В3 & $\begin{array}{l}\text { Sodium/potassium- } \\
\text { transporting ATPase subunit } \\
\text { beta-3 }\end{array}$ & false & 1 & 3 & 3 false \\
\hline Q9Y3Z3 & 1.84 SAMHD1 & $\begin{array}{l}\text { Deoxynucleide triphphate } \\
\text { triphphohydrolase SAMHD1 }\end{array}$ & false & 1 & 2 & 3 false \\
\hline Q9Y3A6 & 1.84 TMED5 & $\begin{array}{l}\text { Transmembrane emp } 24 \\
\text { domain-containing protein } 5\end{array}$ & false & 3 & 3 & 0 false \\
\hline Q13501 & 1.79 SQSTM1 & Sequestome-1 & false & 3 & 1 & 42 true \\
\hline Q96JJ7 & 1.79 TMX3 & $\begin{array}{l}\text { Protein disulfide-isomerase } \\
\text { TMX3 }\end{array}$ & false & 0 & 0 & 0 false \\
\hline O75828 & 1.78 CBR3 & $\begin{array}{l}\text { Carbonyl reductase [NADPH] } \\
3\end{array}$ & false & 2 & 5 & 3 false \\
\hline P35613 & $1.78 \mathrm{BSG}$ & Basigin & false & 2 & 0 & 7 false \\
\hline P26599 & 1.76 РТВР1 & $\begin{array}{l}\text { Polypyrimidine tract-binding } \\
\text { protein } 1\end{array}$ & false & 2 & 0 & 11 false \\
\hline Q9Y295 & 1.76 DRG1 & $\begin{array}{l}\text { Developmentally-regulated } \\
\text { GTP-binding protein } 1\end{array}$ & false & 0 & 1 & 2 false \\
\hline Q7L523 & 1.74 RRAGA & $\begin{array}{l}\text { Ras-related GTP-binding } \\
\text { protein A }\end{array}$ & false & 0 & 3 & 2 false \\
\hline P61009 & 1.7 SPCS3 & $\begin{array}{l}\text { Signal peptidase complex } \\
\text { subunit } 3\end{array}$ & false & 2 & 1 & 1 false \\
\hline Q96HE7 & 1.69 ERO1A & ERO1-like protein alpha & false & 5 & 1 & 1 false \\
\hline
\end{tabular}




\begin{tabular}{|c|c|c|c|c|c|c|c|}
\hline Q9UL46 & 1.66 & PSME2 & $\begin{array}{l}\text { Proteasome activator complex } \\
\text { subunit } 2\end{array}$ & false & 0 & 0 & 2 false \\
\hline Q13724 & 1.63 & MOGS & $\begin{array}{l}\text { Mannyl-oligaccharide } \\
\text { glucidase }\end{array}$ & false & 0 & 2 & 5 false \\
\hline Q9Y5P6 & 1.63 & GMPPB & $\begin{array}{l}\text { Manne-1-phphate } \\
\text { guanyltransferase beta }\end{array}$ & false & 2 & 2 & 1 false \\
\hline P19525 & 1.61 & EIF2AK2 & $\begin{array}{l}\text { Interferon-induced double- } \\
\text { stranded RNA-activated } \\
\text { protein kinase }\end{array}$ & false & 1 & 1 & 18 false \\
\hline P02794 & 1.59 & FTH1 & Ferritin heavy chain & false & 3 & 1 & 5 false \\
\hline P18085 & 1.58 & $\mathrm{ARF} 4$ & ADP-ribylation factor 4 & false & 2 & 10 & 10 false \\
\hline P23381 & 1.57 & WARS1 & $\begin{array}{l}\text { Tryptophan--tRNA ligase } \\
\text { cytoplasmic }\end{array}$ & false & 0 & 0 & 3 false \\
\hline P63244 & 1.56 & RACK1 & $\begin{array}{l}\text { Receptor of activated protein } \\
\text { C kinase } 1\end{array}$ & false & 1 & 0 & 22 false \\
\hline Q9NZ08 & 1.56 & ERAP1 & $\begin{array}{l}\text { Endoplasmic reticulum } \\
\text { aminopeptidase } 1\end{array}$ & false & 1 & 1 & 3 false \\
\hline O95747 & 1.55 & OXSR1 & $\begin{array}{l}\text { Serine/threonine-protein } \\
\text { kinase R1 }\end{array}$ & false & 1 & 1 & 6 false \\
\hline P17858 & 1.54 & PFKL & $\begin{array}{l}\text { ATP-dependent 6- } \\
\text { phphofructokinase liver type }\end{array}$ & false & 1 & 3 & 6 false \\
\hline P08195 & 1.53 & SLC3A2 & $\begin{array}{l}\text { 4F2 cell-surface antigen } \\
\text { heavy chain }\end{array}$ & false & 6 & 0 & 7 false \\
\hline Q9UNN8 & 1.53 & PROCR & $\begin{array}{l}\text { Endothelial protein } \mathrm{C} \\
\text { receptor }\end{array}$ & false & 4 & 8 & 0 false \\
\hline P04439 & 1.51 & HLA-A & $\begin{array}{l}\text { HLA class I histocompatibility } \\
\text { antigen A alpha chain }\end{array}$ & false & 1 & 0 & 5 false \\
\hline P50991 & 1.5 & CCT4 & $\begin{array}{l}\text { T-complex protein } 1 \text { subunit } \\
\text { delta }\end{array}$ & false & 0 & 3 & 11 false \\
\hline
\end{tabular}

\section{Table 2 : Enrichment in biological processes}


Term \%

PValue Associated

GO:0006521 regulation of cellular amino acid metabolic process

GO:0016667 oxidoreductase activity, acting on a sulfur group of donors

GO:0071230 cellular response to amino acid stimulus

GO:0072523 purine-containing compound catabolic process

GO:1901569 fatty acid derivative catabolic process

GO:1901661 quinone metabolic process

0.004

GO:1990928

GO:0034198

response to amino acid starvation

development

(eukin-12

GO:0040019 positive regulation of embryonic

GO:0071470 cellular response to osmotic stress

GO:0051181 cofactor transport

0.004

0.007

negative
stress

GO:0036473 cell death in response to oxidative stress

0.000

stress

GO:1900408 negative regulation of cellular response to oxidative stress

GO:0008631 intrinsic apoptotic signaling pathway in response to oxidative stress

GO:1903201 regulation of oxidative stress-induced cell death

GO:0036475 neuron death in response to oxidative stress Genes

$0.007 \quad 4.48$

0.005

0.001

0.000

0.001

0.003

0.003

0.005

0.004

0.002

0.005

0.001

0.004

0.004

0.003

0.000

0.003

0.003

0.000

0.000

0.000

Nr. Associated Genes Found

Genes

3 [BSG, PSMD6, PSME2]

3 [ERO1A, TMX3, TXNDC17]

4 [ASS1, COL6A1, LAMTOR5, RRAGA]

5.363 [ACOT7, PNP, SAMHD1]

18.753 [ACOT7, LYPLA2, OXCT1]

8.113 [AKR1B1, CBR3, NDUFA9]

5.883 [EIF2AK2, FASN, RRAGA]

6.253 [EIF2AK2, FASN, RRAGA]

5.083 [CDC42, PSME2, SOD2]

5.363 [CDC42, PSME2, SOD2]

6.983 [AKR1B1, OXSR1, RACK1]

5.663 [AKR1B1, LETM1, OXSR1]

5.173 [BSG, OXSR1, SLC9A3R1]

10.003 [BSG, OXSR1, SLC9A3R1]

5.663 [ARF4, CDC42, SLC9A3R1]

5.663 [ARF4, CDC42, SLC9A3R1]

6.253 [ARF4, CDC42, SLC9A3R1]

4.056 [ATP5PB, HSPA4, LETM1, MTX2, NMT1, TIMM13]

$\begin{array}{lll}4.48 & 3 & \text { [HSPA4, NMT1, TIMM13] } \\ 5.88 & 3 & \text { [HSPA4, NMT1, TIMM13] }\end{array}$

6.383 [HSPA4, NMT1, TIMM13]

5 [BSG, NONO, RACK1, SOD2, UBQLN1]

4 [BSG, NONO, RACK1, SOD2]

5 [BSG, NONO, RACK1, SOD2, UBQLN1]

5 [BSG, NONO, RACK1, SOD2, UBQLN1]

$0.000 \quad 6.90 \quad 4$ [BSG, NONO, RACK1, SOD2]

$0.003 \quad 6.25 \quad 3$ [NONO, SOD2, UBQLN1]

$0.000 \quad 6.33$

5 [BSG, NONO, RACK1, SOD2, UBQLN1]

$0.0019 .09 \quad 3$ [BSG, NONO, RACK1]




$\begin{array}{llccc}\text { GO:1903202 } & \begin{array}{l}\text { negative regulation of oxidative stress- } \\ \text { induced cell death }\end{array} & 0.000 & 6.90 & 4 \text { [BSG, NONO, RACK1, } \\ \text { SOD2] }\end{array}$

Table 3 : Enrichment in molecular functions

\begin{tabular}{|c|c|c|c|c|c|}
\hline GOID & GOTerm & $\begin{array}{l}\text { Term } \\
\text { PValue }\end{array}$ & $\begin{array}{l}\text { \% Associated } \\
\text { Genes }\end{array}$ & $\begin{array}{l}\text { Nr. } \\
\text { Genes }\end{array}$ & Associated Genes Found \\
\hline GO:0005518 & collagen binding & 0.009 & 4.05 & 3 & [COL6A1, CTSL, THBS1] \\
\hline GO:0016790 & thiolester hydrolase activity & 0.000 & 10.00 & 4 & $\begin{array}{l}\text { [ACOT7, ACOT9, FASN, } \\
\text { LYPLA2] }\end{array}$ \\
\hline GO:0019210 & kinase inhibitor activity & 0.008 & 4.29 & 3 & [GMFB, RACK1, WARS1] \\
\hline GO:0042169 & SH2 domain binding & 0.002 & 6.52 & 3 & $\begin{array}{l}\text { [KHDRBS1, RACK1, } \\
\text { SQSTM1] }\end{array}$ \\
\hline GO:0042805 & actinin binding & 0.002 & 6.98 & 3 & [LMO7, PALLD, PDLIM7] \\
\hline GO:0051117 & ATPase binding & 0.002 & 4.30 & 4 & $\begin{array}{l}\text { [AKR1B1, ATP1B3, } \\
\text { ATP6V1G1, NSFL1C] }\end{array}$ \\
\hline GO:0016667 & $\begin{array}{l}\text { oxidoreductase activity, acting on a } \\
\text { sulfur group of donors }\end{array}$ & 0.005 & 5.00 & 3 & [ERO1A, TMX3, TXNDC17] \\
\hline GO:0016860 & intramolecular oxidoreductase activity & 0.000 & 6.67 & 4 & $\begin{array}{l}\text { [ERO1A, GNPDA2, PTGES, } \\
\text { TMX3] }\end{array}$ \\
\hline
\end{tabular}

\section{Table 4 : Enrichment using KEGG}

\begin{tabular}{|c|c|c|c|c|c|}
\hline GOID & GOTerm & $\begin{array}{l}\text { Term } \\
\text { PValue }\end{array}$ & $\begin{array}{l}\% \text { Associated } \\
\text { Genes }\end{array}$ & $\begin{array}{l}\text { Nr. } \\
\text { Genes }\end{array}$ & Associated Genes Found \\
\hline KEGG:00051 & $\begin{array}{l}\text { Fructose and mannose } \\
\text { metabolism }\end{array}$ & 0.002 & 9.09 & 3 & [AKR1B1, GMPPB, PFKL] \\
\hline KEGG:04612 & $\begin{array}{l}\text { Antigen processing and } \\
\text { presentation }\end{array}$ & 0.003 & 5.13 & 4 & [CTSL, HLA-A, HSPA4, PSME2] \\
\hline KEGG:04974 & $\begin{array}{l}\text { Protein digestion and } \\
\text { absorption }\end{array}$ & 0.005 & 4.21 & & $\begin{array}{l}\text { [ATP1B3, COL6A1, COL6A3, } \\
\text { SLC3A2] }\end{array}$ \\
\hline
\end{tabular}

\section{Table 5 : Enrichment using reactome}




\begin{tabular}{|c|c|c|c|c|c|}
\hline GOID & GOTerm & $\begin{array}{l}\text { Term } \\
\text { PValue }\end{array}$ & $\begin{array}{l}\% \\
\text { Associated } \\
\text { Genes }\end{array}$ & $\begin{array}{l}\text { Nr. } \\
\text { Genes }\end{array}$ & Associated Genes Found \\
\hline $\begin{array}{l}\text { R- } \\
\text { HSA:1268020 }\end{array}$ & Mitochondrial protein import & 0.001 & 6.25 & 4 & $\begin{array}{l}\text { [MTX2, PITRM1, TIMM13, } \\
\text { TOMM70] }\end{array}$ \\
\hline $\begin{array}{l}\text { R- } \\
\text { HSA:917937 }\end{array}$ & Iron uptake and transport & 0.009 & 5.17 & 3 & $\begin{array}{l}\text { [ATP6V1G1, FTH1, } \\
\text { NEDD8] }\end{array}$ \\
\hline $\begin{array}{l}\text { R- } \\
\text { HSA:9639288 }\end{array}$ & Amino acids regulate mTORC1 & 0.008 & 5.45 & 3 & $\begin{array}{l}\text { [ATP6V1G1, LAMTOR5, } \\
\text { RRAGA] }\end{array}$ \\
\hline $\begin{array}{l}\text { R- } \\
\text { HSA:210991 }\end{array}$ & Basigin interactions & 0.001 & 12.00 & 3 & [ATP1B3, BSG, SLC3A2] \\
\hline $\begin{array}{l}\text { R- } \\
\text { HSA:2173782 }\end{array}$ & $\begin{array}{l}\text { Binding and Uptake of Ligands by } \\
\text { Scavenger Receptors }\end{array}$ & 0.000 & 9.52 & 4 & [ALB, FTH1, HBA1, HSPH1] \\
\hline $\begin{array}{l}\text { R- } \\
\text { HSA:447115 }\end{array}$ & Interleukin-12 family signaling & 0.009 & 5.26 & 3 & [CDC42, PSME2, SOD2] \\
\hline $\begin{array}{l}\text { R- } \\
\text { HSA:8950505 }\end{array}$ & $\begin{array}{l}\text { Gene and protein expression by JAK-STAT } \\
\text { signaling after Interleukin-12 stimulation }\end{array}$ & 0.003 & 7.89 & 3 & [CDC42, PSME2, SOD2] \\
\hline $\begin{array}{l}\text { R- } \\
\text { HSA:9020591 }\end{array}$ & Interleukin-12 signaling & 0.005 & 6.38 & 3 & [CDC42, PSME2, SOD2] \\
\hline $\begin{array}{l}\text { R- } \\
\text { HSA: } 1442490\end{array}$ & Collagen degradation & 0.012 & 4.69 & 3 & [COL6A1, COL6A3, CTSL] \\
\hline $\begin{array}{l}\text { R- } \\
\text { HSA: } 1474290\end{array}$ & Collagen formation & 0.005 & 4.44 & 4 & $\begin{array}{l}\text { [CD151, COL6A1, COL6A3, } \\
\text { CTSL] }\end{array}$ \\
\hline $\begin{array}{l}\text { R- } \\
\text { HSA:186797 }\end{array}$ & Signaling by PDGF & 0.009 & 5.17 & 3 & [COL6A1, COL6A3, THBS1] \\
\hline $\begin{array}{l}\text { R- } \\
\text { HSA:2022090 }\end{array}$ & $\begin{array}{l}\text { Assembly of collagen fibrils and other } \\
\text { multimeric structures }\end{array}$ & 0.001 & 6.56 & 4 & $\begin{array}{l}\text { [CD151, COL6A1, COL6A3, } \\
\text { CTSL] }\end{array}$ \\
\hline $\begin{array}{l}\text { R- } \\
\text { HSA: } 216083\end{array}$ & Integrin cell surface interactions & 0.004 & 4.71 & 4 & $\begin{array}{l}\text { [BSG, COL6A1, COL6A3, } \\
\text { THBS1] }\end{array}$ \\
\hline $\begin{array}{l}\text { R- } \\
\text { HSA:1632852 }\end{array}$ & Macroautophagy & 0.001 & 4.41 & 6 & $\begin{array}{l}\text { [LAMTOR5, RRAGA, } \\
\text { SQSTM1, TOMM70, } \\
\text { TUBA1A, TUBB1] }\end{array}$ \\
\hline $\begin{array}{l}\text { R- } \\
\text { HSA:2995410 }\end{array}$ & Nuclear Envelope (NE) Reassembly & 0.019 & 4.00 & 3 & [BANF1, TUBA1A, TUBB1] \\
\hline $\begin{array}{l}\text { R- } \\
\text { HSA:389957 }\end{array}$ & $\begin{array}{l}\text { Prefoldin mediated transfer of substrate to } \\
\text { CCT/TriC }\end{array}$ & 0.001 & 10.71 & 3 & [CCT4, TUBA1A, TUBB1] \\
\hline $\begin{array}{l}\text { R- } \\
\text { HSA:389958 }\end{array}$ & $\begin{array}{l}\text { Cooperation of Prefoldin and TriC/CCT in } \\
\text { actin and tubulin folding }\end{array}$ & 0.002 & 9.38 & 3 & [CCT4, TUBA1A, TUBB1] \\
\hline $\begin{array}{l}\text { R- } \\
\text { HSA:389960 }\end{array}$ & $\begin{array}{l}\text { Formation of tubulin folding intermediates } \\
\text { by CCT/TriC }\end{array}$ & 0.001 & 12.00 & 3 & [CCT4, TUBA1A, TUBB1] \\
\hline $\begin{array}{l}\text { R- } \\
\text { HSA:5626467 }\end{array}$ & RHO GTPases activate IQGAPs & 0.002 & 9.38 & 3 & [CDC42, TUBA1A, TUBB1] \\
\hline $\begin{array}{l}\text { R- } \\
\text { HSA:8852276 }\end{array}$ & $\begin{array}{l}\text { The role of GTSE1 in G2/M progression } \\
\text { after G2 checkpoint }\end{array}$ & 0.000 & 6.49 & 5 & $\begin{array}{l}\text { [MAPRE1, PSMD6, PSME2, } \\
\text { TUBA1A, TUBB1] }\end{array}$ \\
\hline $\begin{array}{l}\text { R- } \\
\text { HSA:9663891 }\end{array}$ & Selective autophagy & 0.003 & 4.94 & 4 & $\begin{array}{l}\text { [SQSTM1, TOMM70, } \\
\text { TUBA1A, TUBB1] }\end{array}$ \\
\hline
\end{tabular}

\section{Figures}


A

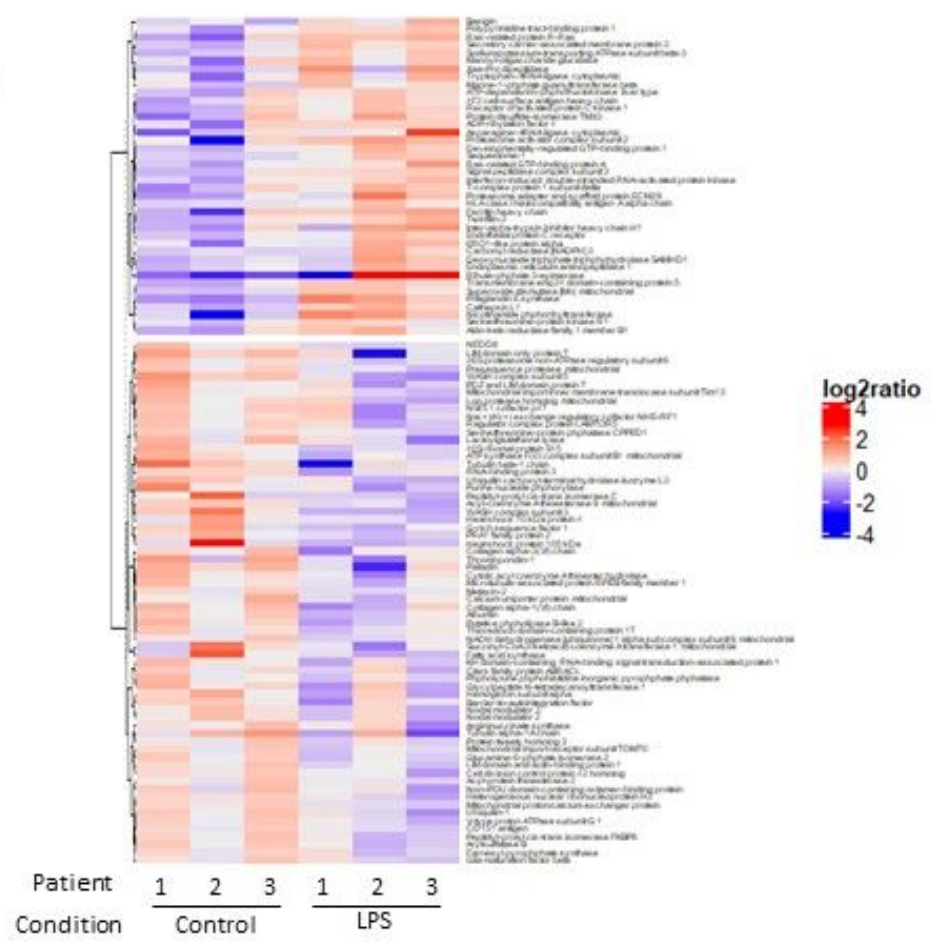

Figure 1

\section{Figure 1}

Heatmap showing differentially expressed proteins by LPS in human synovial cells Human synovial cells from three different patients were treated with LPS $(1 \mu \mathrm{g} / \mathrm{ml})$ for $48 \mathrm{~h}$. At the end of experiments, proteins were extracted and proteomics analysis performed. Differentially expressed proteins between control group and LPS group is shown $(n=3)$ 


\section{A-Biological process}

positive regulation of embryonic development * $10 \%$

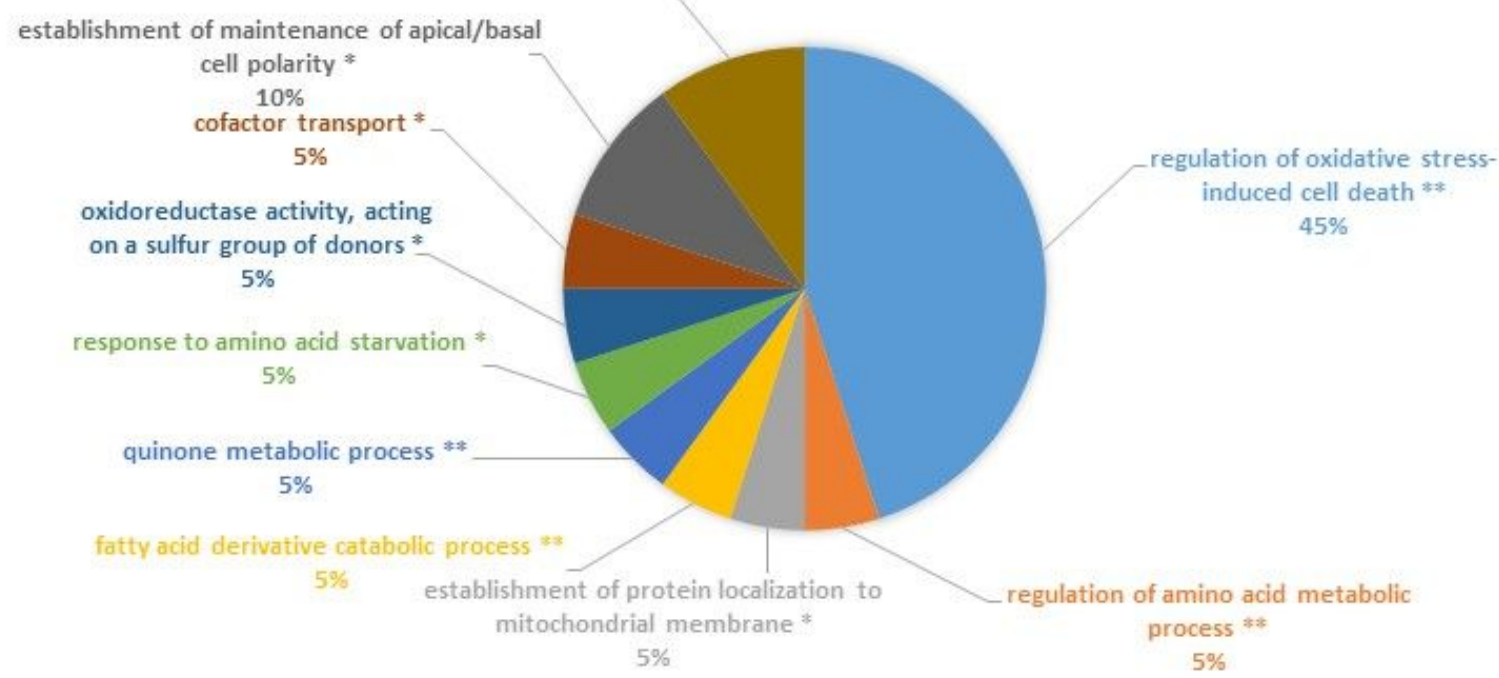

\section{B- Molecular function}

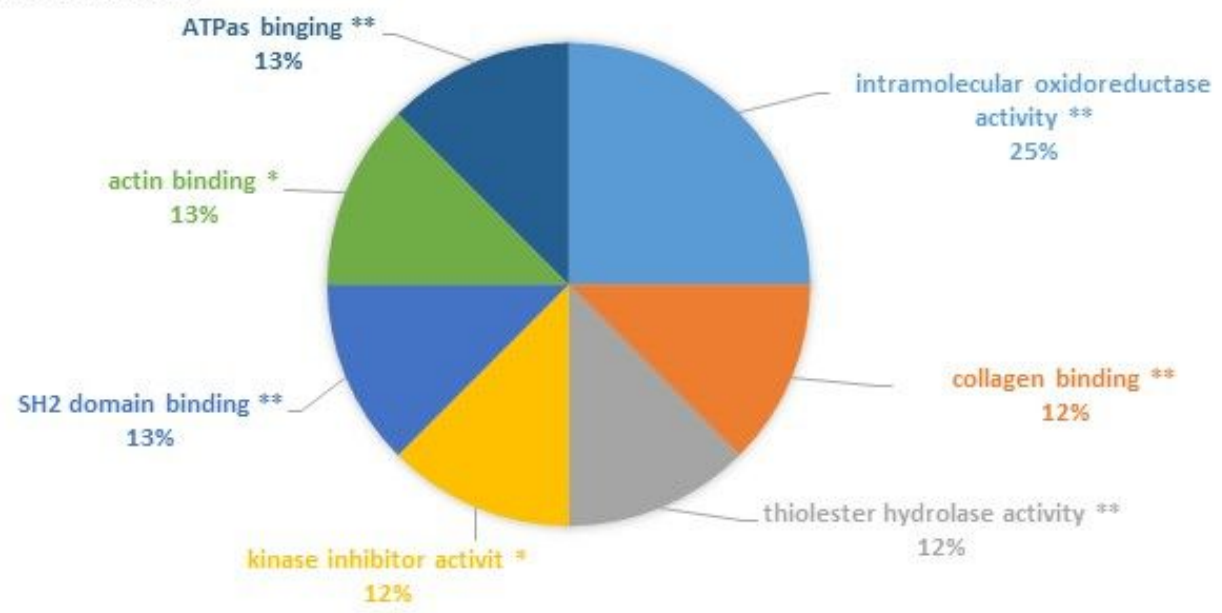

Figure 2

\section{Figure 2}

Enrichment in biological process and molecular function. From differentially expressed proteins between group control and LPS (figure 1), enrichments in biological process (A) and molecular process (B) were performed. Diagrams shows part of each GO Terms which were statistically enriched. *: p-value $<0.05, * \star$ : p-value $<0.01$. 


\section{A- KEGG}

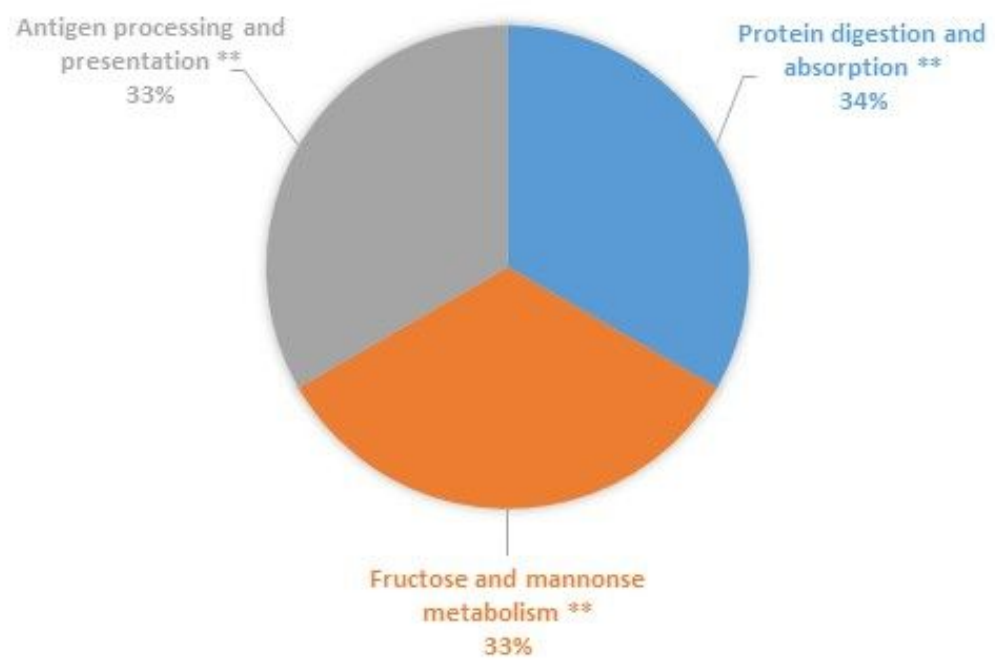

\section{B- Reactome}

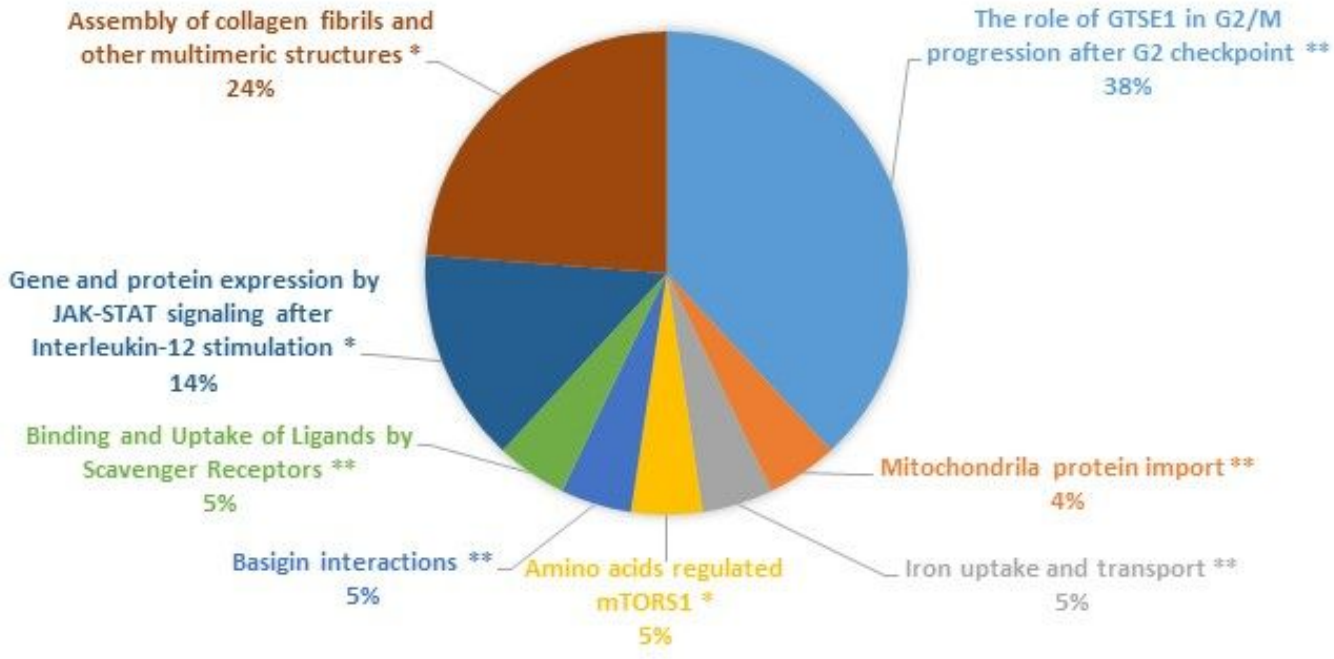

Figure 3

\section{Figure 3}

Enrichment in functional pathways. From differentially expressed proteins between group control and LPS (figure 1), enrichments pathways using KEGG (A) or Reactome (B) datasets were performed. Diagrams shows part of each GO Terms which were statistically enriched. *: p-value $<0.05, * *$ : $p$ value $<0.01$. 

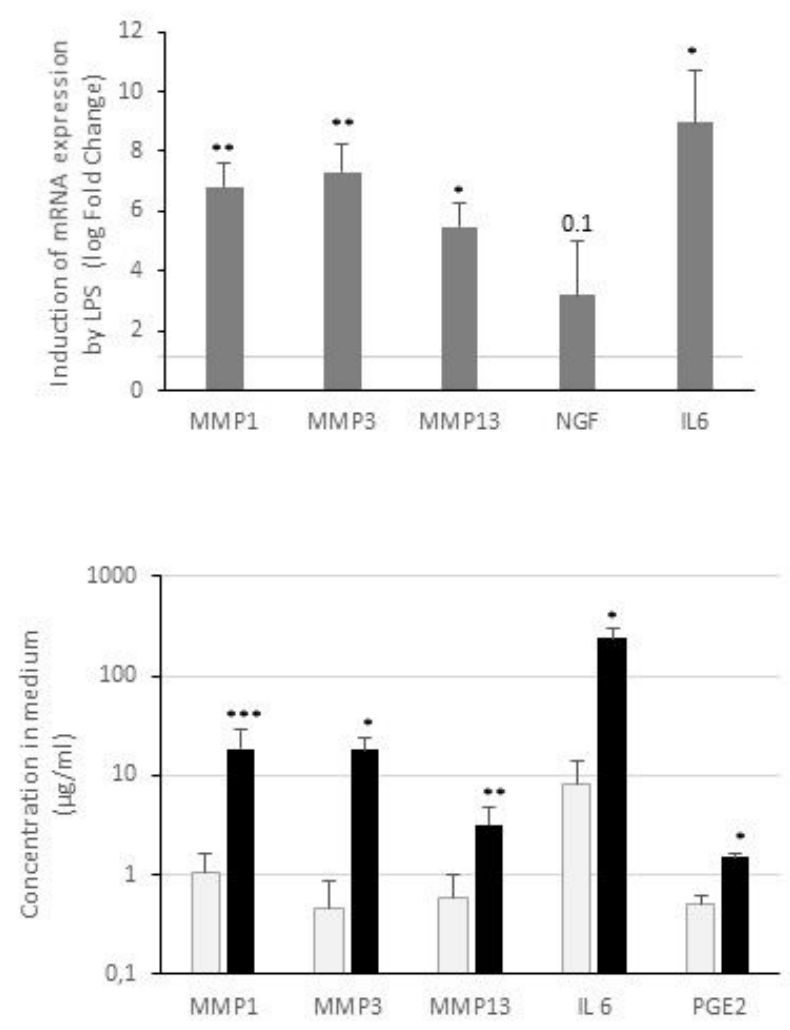

Figure 4

\section{Figure 4}

LPS induces gene expression and release in medium of markers of catabolism, inflammation and pain. Human synovial cells were treated with LPS $(1 \mu \mathrm{g} / \mathrm{ml})$ for $24 \mathrm{~h}$. At the end of experiments, RNA was extracted. Relative mRNA expression of MMP-1, MMP-3, MMP-13, NGF and IL-6 was determined by RTPCR. Values are compared to untreated cells and presented as log Fold Change (compared to control group). Culture medium were collected and ELISA performed to assayed MMP, IL-6 and PGE2 
concentration in medium. Values are expressed as $\mu \mathrm{g} / \mathrm{ml}$ medium $(n=4) . *$ : $p$-value $<0.05, * \star: p$-value<0.01, $\star * *$ : $p$-value $<0.001$.
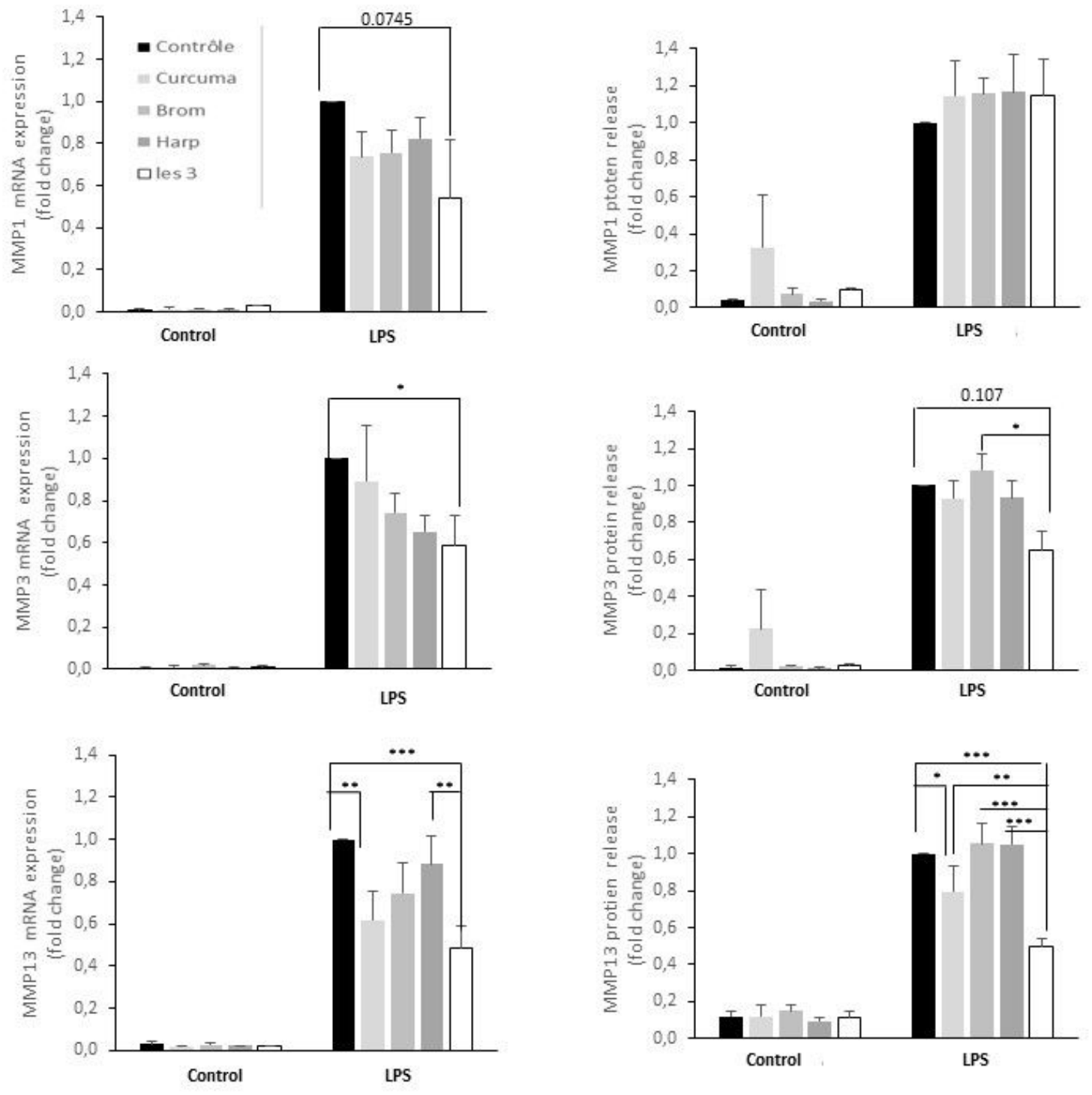

Figure 5

\section{Figure 5}

The association of curcumin with bromelain and harpagophytum significantly reduced the LPS-induced expression of genes associated to catabolism Human synovial cells were treated with LPS $(1 \mu \mathrm{g} / \mathrm{ml})$ for $24 \mathrm{~h}$ in the presence of of curcumin $(13 \mu \mathrm{M})$ with bromelain $(14.7 \mu \mathrm{g} / \mathrm{ml})$, and harpagophytum $(36 \mu \mathrm{g} / \mathrm{ml})$, 
or altogether. At the end of experiments, RNA were extracted and medium collected. Relative mRNA expression of MMP1, MMP3, MMP13 were determined by RT-PCR. Culture media were also collected and ELISA performed to assayed MMP release in medium. Values were compared to LPS-treated cells and presented as relative expression (compared to LPS group). $n=3$. *: $p$-value $<0.05, * *$ : $p$-value $<0.01, * \star \star$ : $p$ value $<0.001$.
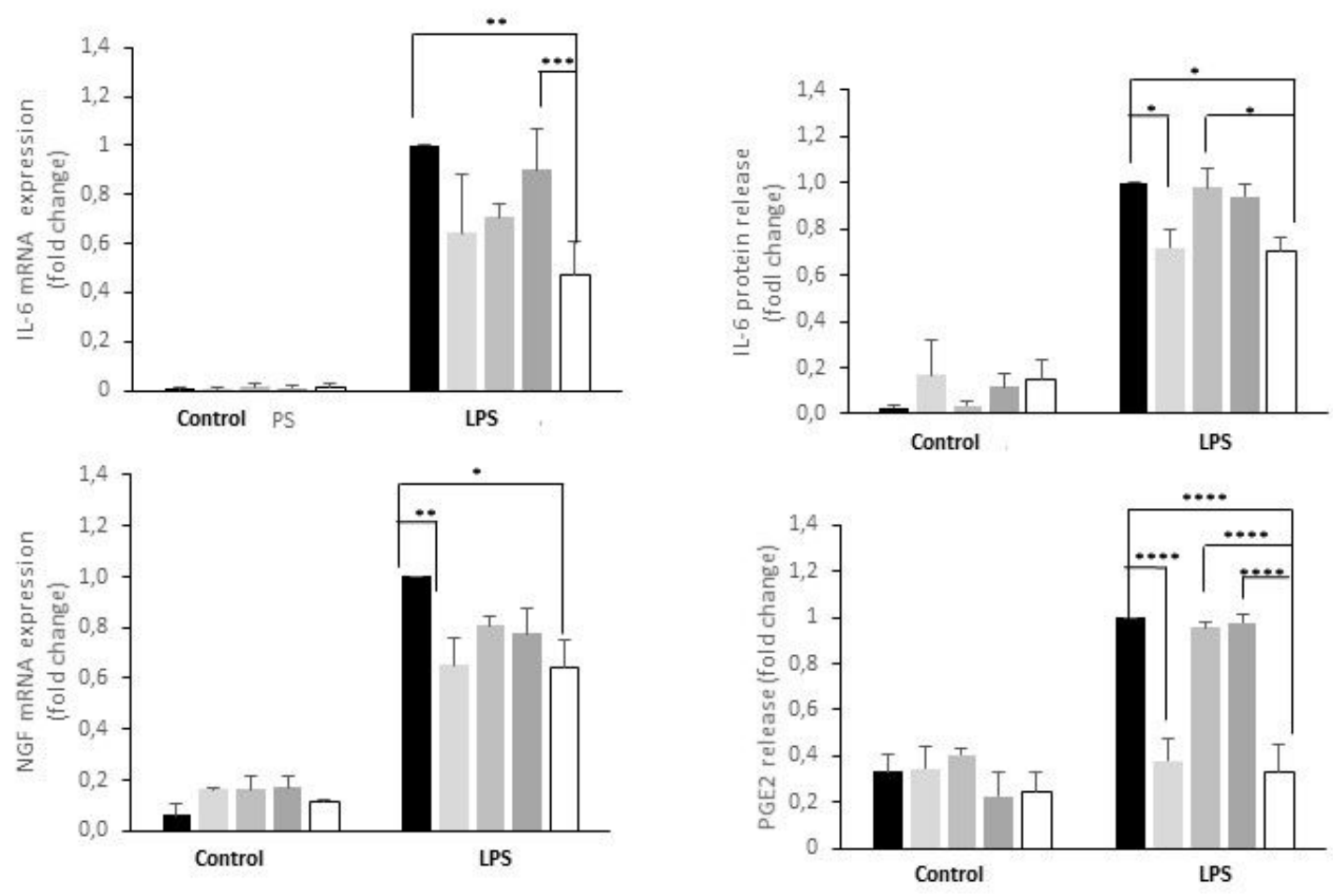

Figure 6 
The association of curcumin with bromelain and harpagophytum significantly reduced the LPS-induced expression of genes associated to inflammation and pain Human synovial cells were treated with (1 $\mu \mathrm{g} / \mathrm{ml})$ for $24 \mathrm{~h}$ in the presence of of curcumin $(13 \mu \mathrm{M})$ with bromelain $(14.7 \mu \mathrm{g} / \mathrm{ml})$, and harpagophytum $(36 \mu \mathrm{g} / \mathrm{ml})$, or altogether. At the end of experiments, RNA were extracted and medium collected. Relative mRNA expression of NGF and IL-6 were determined by RT-PCR. Culture media were also collected and ELISA performed to assayed IL- 6 and PGE2 release in medium. Values were compared to LPS-treated cells and presented as relative release (compared to LPS group). $n=3 . *$ : $p$-value $<0.05, * *$ : $p$-value $<0.01$, $\star \star \star$ : p-value $<0.001$.

\section{Supplementary Files}

This is a list of supplementary files associated with this preprint. Click to download.

- Suppldata1SkeletalVis.xls 